\title{
Occurrence of Corncrakes Crex crex in mosaic farmland landscapes in south-central Sweden - effects of habitat and landscape structure
}

\author{
ÅKE BERG and MATTHEW HIRON
}

\begin{abstract}
Summary
Most studies of Corncrakes have been conducted in grasslands used for hay-cutting, and earlier haycutting has been suggested as the main cause of population decline in this species. Less is known about habitat preferences in relation to other land-uses and landscape structure. This paper investigated habitat composition and landscape structure in territories and at random sites in arable fields and meadows in south-central Sweden. Calling Corncrakes preferred sites with tall vegetation, moist ground, and locations close to ditches (55\% of territories). Suitable conditions occurred on abandoned unmanaged wet meadows (31\% of territories), mown wet meadows (14\%), leys (30\%) and non-rotational set-asides ( $15 \%$ of territories). Corncrakes avoided annual crops and other crops with short vegetation in the spring. Cutting of vegetation before mid-July was recorded in $21 \%$ of the territories and resulted in $100 \%$ abandonment of these sites. In contrast to many other ground nesting farmland birds, Corncrakes did not avoid forest edges ( $42 \%$ of territories within $100 \mathrm{~m}$ of edges). A strategy to conserve Corncrake populations should focus on maintenance of moist natural and sown grasslands (unmanaged or mown late) with tall vegetation and prevention of succession to woodland. Target areas should be in forested landscapes, because many other meadow birds that are more dependent on management (e.g. yearly mowing or grazing) prefer open landscapes.
\end{abstract}

\section{Introduction}

The Corncrake Crex crex was formerly widespread in wet meadows in Europe; however, the area of wet meadows has decreased drastically due to reclamation and abandonment during modernisation of farming. Furthermore, the quality of this habitat for breeding has been reduced by earlier mowing in remaining meadows, conversion of meadows to pastures and increased grazing pressure in many areas (Bernes 1993, Chamberlain and Fuller 2000, Evans 2004). The decreased area of meadows and changes in management have been detrimental to Corncrakes, which breed late in the season (June-July), i.e. during the time when mowing takes place (Green et al. 1997, Berg and Gustafson 2007). The mechanism behind the decline is lowered reproductive success due to destruction of nests and killing of chicks during mowing of grasslands (Green 2008). The Corncrake declined considerably in numbers during the last century and has been classified as of global conservation concern (Birdlife International 2004) and later as 'Least Concern' (IUCN 2010); the species is now classified as 'Near Threatened' in Sweden (Gärdenfors 2010). Abandoned, unmanaged wet meadows seem to be the most preferred habitat in northern Europe (Keiss 1997, Berg and Gustafson 2007, Keiss and Mednis 2006). Corncrakes also occur in other grasslands such as extensively managed set-asides (fallows), and intensively managed leys (Keiss 1997, Ottvall and Pettersson 1998a,b, Berg and Gustafson 2007).

Despite a dramatic long-term decline, the number of calling Corncrakes has increased during the last three decades (BirdLife International 2004, Keiss and Mednis 2006, Pettersson 2007). A 
possible reason for this recent increase is abandonment of farmland, such as meadows and arable fields (Keiss and Mednis 2006). The preference for unmanaged arable habitats in relation to managed habitats (leys) is largely unknown. In particular, information on the importance of setasides as breeding habitat has been requested (Pettersson 2007).

In south-central Sweden, Corncrakes occur on the same meadows as other declining farmland birds that are dependent on management, such as waders and passerines. The reintroduction of grazing on meadows has so far been the main measure for increasing the populations of these management-dependent species. However, this may be in conflict with the conservation of Corncrakes, which prefer tall vegetation (Green et al. 1997, Schäffer 1999, Berg and Gustafson 2007).

Many farmland birds nest in the edge zone and forage in open fields, and are therefore attracted to edge habitats (Andrén 1995, Pärt and Söderström 1999, Berg 2002, Gustafson 2006). However, ground-nesting farmland bird species generally avoid forest edges and perches (e.g. single trees and shrubs) used by avian predators (Stroud et al. 1990, Berg et al. 1992, Wallander et al. 2006). Despite this, it is not clear if Corncrakes also avoid forest edges.

In addition to field type and landscape structure (amount of forest), occurrence of residual habitats (ditches, edge zones, within-field habitat islands) has been shown to be important to the bird fauna in farmland (Berg 2002, Herzon and O'Hara 2007). Ditches attract species associated with wetlands (and presumably also moist meadows) and species associated with tall vegetation (reviewed in Herzon and Helenius 2008). Ditches are therefore expected to be preferred by Corncrakes, especially on intensively managed and dry arable fields, although this has not been studied in detail.

The specific aims of the present study were to analyse habitat preferences in relation to 1) meadow management (unmanaged, grazed and mown sites), 2) type of arable fields (annual crops and especially the relative importance of leys and set-asides), 3) occurrence of ditches, moisture and distance to wetland, 4) landscape structure (distance to closest forest edge) and to 5) estimate the proportion of territories that are influenced by management practices (mowing and clearing of vegetation) during the breeding season.

\section{Methods}

\section{Study areas}

Corncrakes were censused in 12 study areas (total area $291 \mathrm{~km}^{2}$ of open farmland) during 2006 and 2007 in the counties of Uppland and Västmanland in south-central Sweden (for details see Berg 2008). The smallest study areas were $5 \mathrm{~km}^{2}$ (Baggådalen and Fyrisån) and the largest area was $59 \mathrm{~km}^{2}$ (Svartådalen), see Table 2 .

The selection of study sites was based on observations of Corncrakes during previous years. Several study areas were situated near lakes and rivers with large proportions of the farmland consisting of meadows. However, the selected areas differed largely in landscape structure and habitat composition. Some study areas were located in intensively managed agricultural plains with intensive farming (dominated by spring- and autumn-sown cereals), others in more forested landscapes with less intensive farming and large areas of leys and non-rotational set-asides, see Table 2 for details.

\section{Census methods and habitat mapping}

All study areas were visited twice during night time (23hoo-04hoo when Corncrakes call); once during the period 25 May-15 June and once during the period 16 June-5 July. Study areas were only visited during nights with good weather conditions, i.e. without rain or strong winds. The study areas were monitored from roads by stopping and listening for Corncrakes for five minutes at suitable sites every $500 \mathrm{~m}$. Most Corncrakes could be heard at distances up to $1 \mathrm{~km}$. The exact position of the calling Corncrakes was located from a closer distance (50-10om) and 
noted on a map. All territories (sites with Corncrakes calling at least once within a $200 \mathrm{~m}$ radius, see Ottvall and Pettersson (1998a,b) for data on territory size) were visited also during daytime during both period 1 and period 2 (within three days of the observation). Type of crop, habitat and landscape structure, and management were classified according to Table 1 . Distances to closest forest edge, meadow and closest wetland (lake, creek or small wetland) were estimated from maps and occurrence of ditches within $200 \mathrm{~m}$ was recorded. Moisture was classified from dry to wet on a scale of $I$ to 4 . Occurrence of grazing animals and mowing or clearing of vegetation were recorded on each visit. The territories were also visited once during daytime in the period 5 July20 July, and changes in the habitat (within $200 \mathrm{~m}$ ) such as hay-cutting in meadows and leys and clearing of vegetation in set-asides were noted. During this visit, playback of Corncrake calls (for at least five minutes) was used to stimulate response from territorial Corncrakes.

In total, 257 random points in arable fields and meadows were mapped in a similar way during period $I$ and period 2. Points in woodlands, built up areas and other "non-habitats" were excluded. A grid $(100 \times 100 \mathrm{~m})$ was used for random selection of $13-38$ random sites in each area (depending on area size). These random sites were used to compare habitat composition in random sites and Corncrake territories.

\section{Analyses}

An analysis of habitat preferences (type of arable field and meadow, and occurrence of ditches included) during period I (25 May-15 June, 70 territories) and period 2 (16 June-5 July, 84 territories) showed no significant differences between periods (Chi-square-tests, $\chi^{2}=1.1, P>$ o.9). Therefore, observations from the two periods were pooled in the main analyses (see below).

Habitat preferences of Corncrakes were analysed by comparing habitat composition in random sites and Corncrake territories using generalised linear mixed models (GLMM) with a binomial distribution and a logit link function. All analyses were run in $\mathrm{R}$ using the lme4 package (Bates and Maechler 2010, R Development Core Team 2010). The explanatory variables used in candidate model sets (one for each year) were: habitat (seven categories), occurrence of ditches, moisture (scale 1-4), distance to forest edge and wetland (log distances in m). Site $(n=12)$ was used as a random factor. Distance to nearest meadow (same in both periods) and moisture during period 2

Table 1. Habitat factors noted in Corncrake territories and random sites.

\begin{tabular}{|c|c|}
\hline Habitat type & Habitat elements \\
\hline $\begin{array}{l}\text { Wet meadows (natural vegetation) } \\
\text { Grazed meadow (varied grazing pressure) } \\
\text { Wet meadow used for mowing (cut in mid-July) } \\
\text { Unmanaged wet meadow } \\
\quad \text { (with scattered Salix shrubs) }\end{array}$ & Ditch $(<3$ m wide), within $200 m$ radius \\
\hline $\begin{array}{l}\text { Arable fields (sown vegetation) } \\
\text { Annual crops (Spring-sown and } \\
\text { autumn-sown rotational crops } \\
\text { Ley (grass/clover), cut for silage or hay } \\
\text { Non-rotational set-aside (tall grass vegetation) } \\
\text { Other crops (with short vegetation)* }\end{array}$ & $\begin{array}{l}\text { Distance to habitat elements (m) } \\
\text { Forest edge } \\
\text { Wetland (creek, lake, pond) } \\
\text { Meadow }\end{array}$ \\
\hline $\begin{array}{l}\text { Grazing and mowing } \\
\text { Occurrence (Yes/No) } \\
\text { Mowing done (Yes/No) }\end{array}$ & $\begin{array}{l}\text { Moisture/Flooding } \\
\text { Moisture in four-degree scale (dry-moist-some } \\
\text { standing water-largely flooded) during } \\
\text { visit } 1 \text { and } 2^{* *}\end{array}$ \\
\hline
\end{tabular}

${ }^{*}$ Includes rotational set-asides and cultivated pasture.

${ }^{* *}{ }_{1}=$ dry, $2=$ damp, moisture in ground, $3=$ areas of standing water, $4=$ largely flooded. 
Table 2. Area, number or random sites, mean distance to forest edge for random sites, number of Corncrake territories and density of territories in the 12 study area in 2006 and 2007 (upper table). Mean proportion of different habitats (arable fields and wet meadows) in the 12 study areas (lower table).

\begin{tabular}{|c|c|c|c|c|c|c|c|}
\hline \multirow[t]{2}{*}{ Site } & \multirow[t]{2}{*}{ Area $\left(\mathrm{km}^{2}\right)$} & \multirow{2}{*}{$\begin{array}{l}\text { No. of } \\
\text { random } \\
\text { sites }\end{array}$} & \multirow{2}{*}{$\begin{array}{l}\text { Distance } \\
\text { to forest } \\
(\mathrm{m})\end{array}$} & \multicolumn{2}{|l|}{2006} & \multicolumn{2}{|l|}{2007} \\
\hline & & & & $\begin{array}{l}\text { No. of } \\
\text { terr. }\end{array}$ & Terr. $/ \mathrm{km}^{2}$ & No. of terr. & Terr./ $\mathrm{km}^{2}$ \\
\hline Alunda & $33 \cdot 9$ & 21 & 142 & o & o & 2 & 0.06 \\
\hline Bälinge mossar & 21.5 & 19 & 124 & 1 & 0.05 & 5 & 0.23 \\
\hline Dannemora & $19 \cdot 3$ & 13 & 96 & 2 & 0.1 & 1 & 0.05 \\
\hline Fyrisån & 5 & 18 & 186 & 1 & 0.2 & 1 & 0.2 \\
\hline Marma skjutfält & 8 & 14 & 97 & 7 & 0.88 & 25 & 3.13 \\
\hline Torstuna & $34 \cdot 4$ & 31 & 233 & 12 & 0.35 & 7 & 0.2 \\
\hline Tegelsmora & 12.1 & 15 & 133 & 5 & 0.41 & 4 & 0.33 \\
\hline Baggådalen & 4.9 & 15 & 146 & 1 & 0.2 & 2 & 0.41 \\
\hline Gnien & 17.8 & 20 & 178 & o & o & 4 & 0.22 \\
\hline Skultuna & 31.4 & 23 & 145 & 2 & 0.06 & o & $\mathrm{o}$ \\
\hline Svartådalen & 59 & 38 & 182 & 14 & 0.24 & 9 & 0.15 \\
\hline Vibyslätten & $44 \cdot 4$ & 30 & 314 & 4 & 0.09 & 4 & 0.09 \\
\hline Total/Mean & 291.7 & 257 & 165 & 49 & 0.17 & 64 & 0.22 \\
\hline \multirow[t]{2}{*}{ Site } & \multicolumn{7}{|c|}{ Proportion of different habitats } \\
\hline & $\begin{array}{l}\text { Grazed } \\
\text { wet } \\
\text { meadow }\end{array}$ & $\begin{array}{l}\text { Mowed } \\
\text { wet } \\
\text { meadow }\end{array}$ & $\begin{array}{l}\text { Unmanaged } \\
\text { wet } \\
\text { meadow }\end{array}$ & $\begin{array}{l}\text { Other } \\
\text { crops* }^{*}\end{array}$ & $\begin{array}{l}\text { Non-rotational } \\
\text { set-aside }\end{array}$ & Ley & $\begin{array}{l}\text { Annual } \\
\text { crops }^{* *}\end{array}$ \\
\hline Alunda & 0.000 & 0.000 & 0000 & 0.095 & 0.048 & 0.310 & 0.548 \\
\hline Bälinge mossar & 0.105 & 0.000 & 0.263 & 0.000 & 0.158 & 0.184 & 0.289 \\
\hline Dannemora & 0.000 & 0.000 & 0.231 & 0.154 & 0.154 & 0.385 & 0.077 \\
\hline Fyrisån & 0.333 & 0.056 & 0.056 & 0.000 & 0.111 & 0.333 & 0.111 \\
\hline Marma skjutfält & 0.071 & 0.143 & 0.143 & 0.143 & 0.000 & 0.214 & 0.286 \\
\hline Torstuna & 0.000 & 0.000 & 0.065 & 0.000 & 0.016 & 0.113 & 0.806 \\
\hline Tegelsmora & 0.133 & 0.000 & 0.067 & 0.233 & 0.200 & 0.267 & 0.100 \\
\hline Baggådalen & 0.133 & 0.000 & 0.133 & 0.000 & 0.333 & 0.167 & 0.233 \\
\hline Gnien & 0.225 & 0.000 & 0.075 & 0.100 & 0.150 & 0.125 & 0.325 \\
\hline Skultuna & 0.043 & 0.000 & 0.000 & 0.043 & 0.109 & 0.087 & 0.717 \\
\hline Svartådalen & 0.184 & 0.132 & 0.079 & 0.013 & 0.132 & 0.105 & 0.355 \\
\hline Vibyslätten & 0.033 & 0.000 & 0.000 & 0.200 & 0.033 & 0.100 & 0.633 \\
\hline Total/Mean & 0.105 & 0.027 & 0,093 & 0.082 & 0.120 & 0.199 & 0.373 \\
\hline
\end{tabular}

${ }^{*}$ With short vegetation, include rotational set-asides and cultivated pasture, pooled since they were uncommon.

**Spring-sown and autumn-sown crops.

were excluded from the analyses since they were strongly correlated to distance to wetland $\left(r_{\mathrm{s}}=\right.$ 0.70, $P<0.001)$ and moisture during period $1\left(\mathrm{r}_{\mathrm{s}}=0.91, P<0.001\right)$, respectively. Moisture during period $I$ was selected for analysis since moisture at territory establishment was assumed to influence occurrence of territory selection more than moisture later in the season.

Akaike's information criterion (AICc corrected for small sample size) was used for evaluation of different models (Burnham and Anderson 2002). Individual models $(n=31$ possible candidate models) were ranked according to $\triangle \mathrm{AICc}\left(\mathrm{AIC}_{\mathrm{i}}-\mathrm{AICc}_{\mathrm{min}}\right)$, where the best model has $\triangle \mathrm{AICc}=0$ ). Thereafter, Akaike weights $\left(w_{i}\right)$ were calculated for each model. The Akaike weights $\left(w_{i}\right)$ indicate the "weight" of evidence for individual models in relation to other models in the candidate set. Akaike weights were also used to calculate model-averaged coefficients for all models with $\Delta$ AICc $<$ 10. Relative importance was calculated by summing Akaike weights for all models with 
a $\triangle \mathrm{AICc}<$ 10 containing that variable. All model comparisons and model averaging were performed in the MuMIn package in $\mathrm{R}$ (Barton 2010).

\section{Results}

In total, 113 Corncrake territories were recorded in the 12 study areas (49 territories in 2006 and 64 in 2007). The number of territories and territory density in the 12 study areas differed considerably (Table 2).

The multi-model comparison of random sites and Corncrake territories showed that field type was the main factor that differed between random sites and territories in both years, with a relative variable importance of 1.0 in both years (Tables 3 and 4 ). Corncrakes occurred more often than expected (i.e. compared to habitat composition among random points) on unmanaged wet meadows ( $31 \%$ of territories, $8 \%$ of random points), wet meadows used for mowing ( $14 \%$ of territories, $3 \%$ of random points), leys ( $30 \%$ of territories, $18 \%$ of random points) and nonrotational set-asides ( $15 \%$ of territories, $11 \%$ of random points). Annual crops and other crops with short vegetation harboured far fewer Corncrake territories (4\%) than expected by a random settlement ( $43 \%$ of random points). The pattern was similar in both years (Fig. 1).

The density of Corncrakes could be expected to be higher in areas with high proportions of preferred habitats. However, the density of Corncrake territories in the 12 study sites (mean value for 2006 and 2007) was not correlated with the total proportion of preferred habitat (i.e. total

Table 3. Multi model comparisons ( $\mathrm{AICc}$ and $\mathrm{AICc}_{\mathrm{w}}$ ) between GLMM habitat models comparing Corncrake territories and random sites in 2006 and 2007 . The presented models had a $\triangle \mathrm{AICc}<10$ and included different combinations of the variables habitat (seven categories), moisture (4 degree scale), distance to forest and meadow (both continuous variables) and occurrence of ditches. Site was included as a random factor in all models.

\begin{tabular}{|c|c|c|c|c|c|c|}
\hline \multirow[t]{2}{*}{ Rank } & \multicolumn{3}{|l|}{2006} & \multicolumn{3}{|l|}{2007} \\
\hline & Model & $\mathrm{AICc}$ & $\mathrm{AICc}_{\mathrm{w}}$ & Model & $\mathrm{AICc}$ & $\mathrm{AICc}_{\mathrm{w}}$ \\
\hline 1 & $\begin{array}{l}\text { Ditch+DistForest+Habitat+ } \\
\text { Moisture }\end{array}$ & 213.1 & 0.18 & $\begin{array}{l}\text { Ditch+DistWetl+Habitat+ } \\
\text { Moisture }\end{array}$ & 243.2 & 0.18 \\
\hline 2 & Ditch + Habitat+Moisture & 214.1 & 0.11 & Ditch+Habitat & 243.6 & 0.15 \\
\hline 3 & Ditch+DistForest+Habitat & 214.2 & 0.11 & Ditch+Habitat+Moisture & 243.8 & 0.13 \\
\hline 4 & Ditch+Habitat & 214.2 & 0.11 & $\begin{array}{l}\text { Ditch+DistForest+DistWetl+ } \\
\text { Habitat+Moisture }\end{array}$ & 244.1 & 0.11 \\
\hline 5 & DistForest+Habitat+Moisture & 214.6 & 0.09 & Ditch+DistWetl+Habitat & 244.1 & 0.11 \\
\hline 6 & $\begin{array}{l}\text { Ditch+DistForest+DistWetl+ } \\
\text { Habitat+Moisture }\end{array}$ & 214.9 & 0.07 & Ditch+DistForest+Habitat & $244 \cdot 5$ & 0.09 \\
\hline 7 & $\begin{array}{l}\text { Ditch+DistWetl+Habitat+ } \\
\text { Moisture }\end{array}$ & 215.5 & 0.06 & $\begin{array}{l}\text { Ditch+DistForest+Habitat+ } \\
\text { Moisture }\end{array}$ & 244.6 & 0.09 \\
\hline 8 & DistForest+Habitat & 215.7 & 0.05 & $\begin{array}{l}\text { Ditch+DistForest+DistWetl+ } \\
\text { Habitat }\end{array}$ & 245.2 & 0.06 \\
\hline 9 & Habitat+Moisture & 216.0 & 0.04 & Habitat & 247.8 & 0.02 \\
\hline 10 & Habitat & 216.1 & 0.04 & Habitat+Moisture & 248.3 & 0.01 \\
\hline 11 & Ditch+DistWetl+Habitat & 216.1 & 0.04 & DistWetl+Habitat+Moisture & 248.9 & 0.01 \\
\hline 12 & $\begin{array}{l}\text { Ditch+DistForest+DistWetl+ } \\
\text { Habitat }\end{array}$ & 216.3 & 0.04 & DistForest+Habitat & 249.0 & 0.01 \\
\hline 13 & $\begin{array}{l}\text { DistForest+DistWetl+Habitat+ } \\
\text { Moisture }\end{array}$ & 216.7 & 0.03 & DistWetl+Habitat & 249.2 & 0.01 \\
\hline 14 & DistForest+DistWetl+Habitat & $217 \cdot 7$ & 0.02 & DistForest+Habitat+Moisture & $249 \cdot 4$ & 0.01 \\
\hline 15 & DistWetl+Habitat+Moisture & 218.0 & 0.02 & $\begin{array}{l}\text { DistForest+DistWetl+Habitat+ } \\
\text { Moisture }\end{array}$ & 250.0 & O.01 \\
\hline 16 & DistWetl+Habitat & 218.2 & 0.01 & DistForest+DistWetl+Habitat & 250.4 & $<0.001$ \\
\hline
\end{tabular}


Table 4. Parameter estimates (with upper and lower $95 \%$ confidence limits) from GLMM habitat models comparing Corncrake territories and random sites in 2006 and 2007. Coefficients are averaged across all models with $\triangle \mathrm{AICc}<10$ and weighted by their AICc score. Relative variable importance shows the likelihood that each variable has a genuine effect on Corncrake occurrence. Coefficient estimates for habitat categories are relative to the reference category annual crops.

\begin{tabular}{|c|c|c|c|c|c|c|c|c|c|}
\hline \multirow[t]{2}{*}{ Variable } & \multicolumn{3}{|l|}{2006} & \multirow{2}{*}{$\begin{array}{l}\text { Relative } \\
\text { importance }\end{array}$} & \multirow[t]{2}{*}{ Variable } & \multicolumn{3}{|l|}{2007} & \multirow{2}{*}{$\begin{array}{l}\text { Relative } \\
\text { importance }\end{array}$} \\
\hline & Coefficient & Lower CI & Upper CI & & & Coefficient & Lower CI & Upper CI & \\
\hline (Intercept) & $-4 \cdot 32$ & -7.41 & -1.23 & & (Intercept) & $-4,7$ & -7.67 & -1.73 & \\
\hline Ditch & 0.587 & -0.422 & 1.6 & 0.71 & Ditch $^{*}$ & 0.932 & 0.081 & 1.78 & 0.92 \\
\hline DistForest & -0.482 & -1.58 & 0.618 & 0.58 & DistForest & -0.249 & -1.07 & 0.577 & 0.39 \\
\hline DistWetl & 0.0431 & -0.25 & 0.336 & 0.28 & DistWetl & 0.221 & -0.365 & 0.806 & 0.5 \\
\hline Hab., grazed meadow & 2.07 & -0.112 & 4.25 & 1 & Habitat, grazed meadow & 1.59 & -0.36 & 3.53 & 1 \\
\hline Hab., ley* & 3.01 & 1.36 & 4.67 & 1 & Hab., ley* & 2.53 & 1.09 & 3.97 & 1 \\
\hline Hab., mowed meadow ${ }^{*}$ & 4.03 & 1.96 & 6.1 & 1 & Hab., mowed meadow ${ }^{*}$ & 2.42 & 0.519 & $4 \cdot 31$ & 1 \\
\hline Hab., non-rotational set-aside* & 3.09 & 1.3 & 4.88 & 1 & Hab., non-rotational set-aside & 2.81 & 1.27 & $4 \cdot 35$ & 1 \\
\hline Hab., other crops & $-13 \cdot 5$ & -3500 & 3470 & 1 & Hab., other crops & -14.1 & -2940 & 2910 & 1 \\
\hline Hab., Unmanaged meadow ${ }^{*}$ & $3 \cdot 72$ & 1.84 & 5.61 & 1 & Hab., unmanaged meadow ${ }^{*}$ & $3 \cdot 74$ & 2.12 & $5 \cdot 35$ & 1 \\
\hline Hab., annual crops & o & & & 1 & Hab., annual crops & o & & & 1 \\
\hline Moisture & 0.297 & -0.357 & 0.951 & 0.59 & Moisture & 027 & -0.38 & 0921 & 0.55 \\
\hline
\end{tabular}

${ }^{*}$ Denotes coefficients with error margins that do not include zero. 

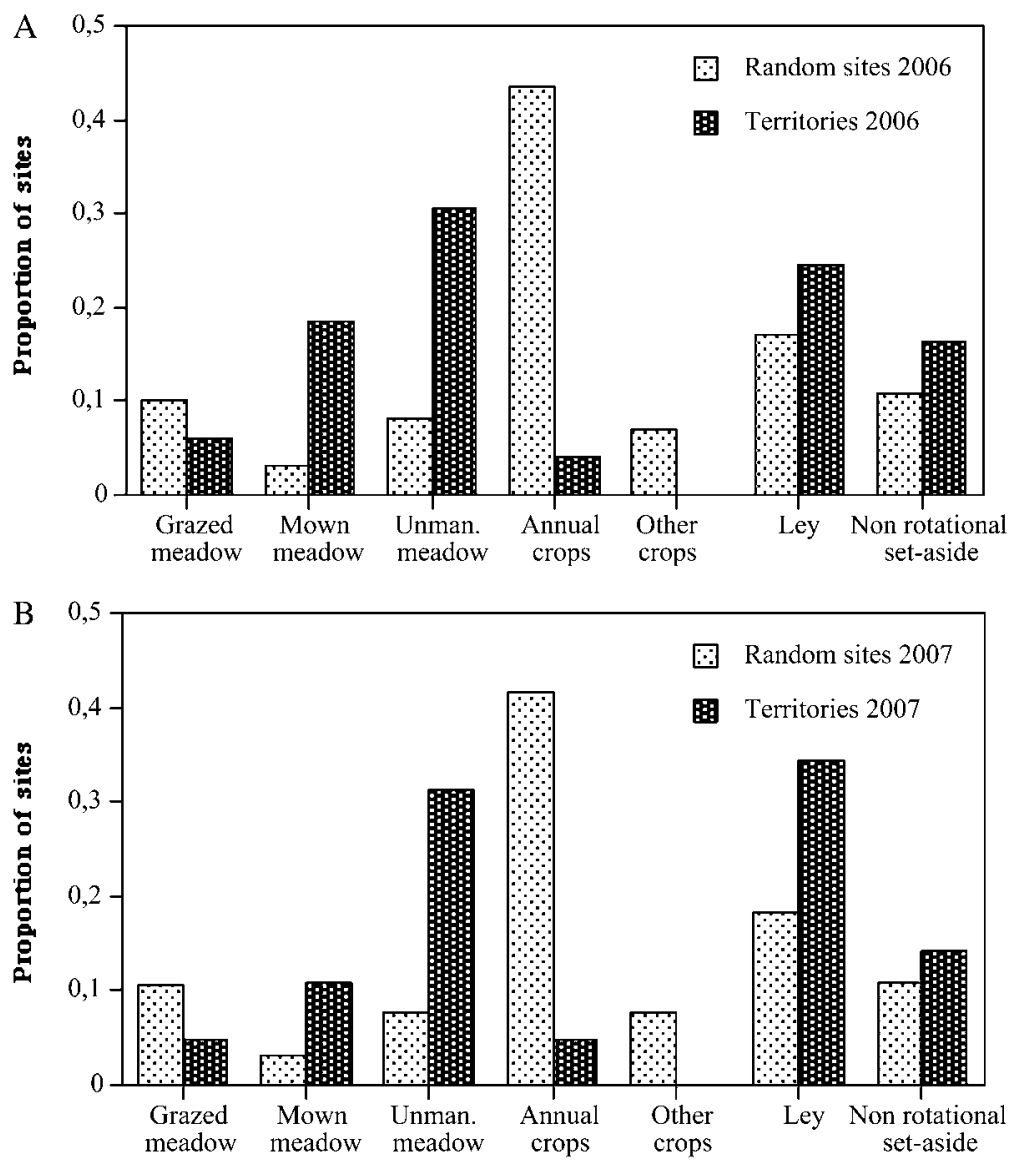

Fig. I a) Proportion of Corncrake territories $(n=49)$ and random sites $(n=257)$ with different habitat (in centre of territories and random sites) in 2006. b) Proportion of Corncrake territories $(n=64)$ and random sites $(n=257)$ with different habitat (in centre of territories and random sites) in 2007 .

proportion of unmanaged wet meadow, ley, non-rotational set-aside and wet meadows used for mowing) in different study areas, or to the proportion of single preferred habitats (Pearson correlation analyses, all $P$ values $>$ o.1).

The multi-model comparison of random sites and Corncrake territories suggested that ditches were of importance for Corncrakes, especially in 2007 (Tables 3 and 4). The difference in importance of ditches between years is indicated by the changes in relative importance, parameter estimates and confidence intervals for that variable in 2006 and 2007 respectively (Table 4). Ditches occurred in $43 \%$ and $64 \%$ of the territories in 2006 and 2007 , respectively, but only in $21 \%$ of the random sites. Ditches seemed to be equally important in preferred arable habitats (leys and non-rotational set-asides) where ditches occurred in $34 \%$ of the random sites and in $61 \%$ of the territories and in preferred meadow habitats (unmanaged meadows and mowed meadows) where ditches occurred in $37 \%$ of the random sites and in $56 \%$ of the territories. The interaction habitat $\mathrm{x}$ ditch was not included in the final analyses, since exploratory analyses showed that the Akaike weight for this interaction was very low $(<$ o.01). The median moisture in Corncrake territories in the two years was 2 (moist) compared to a median moisture of $I$ (dry) in random 


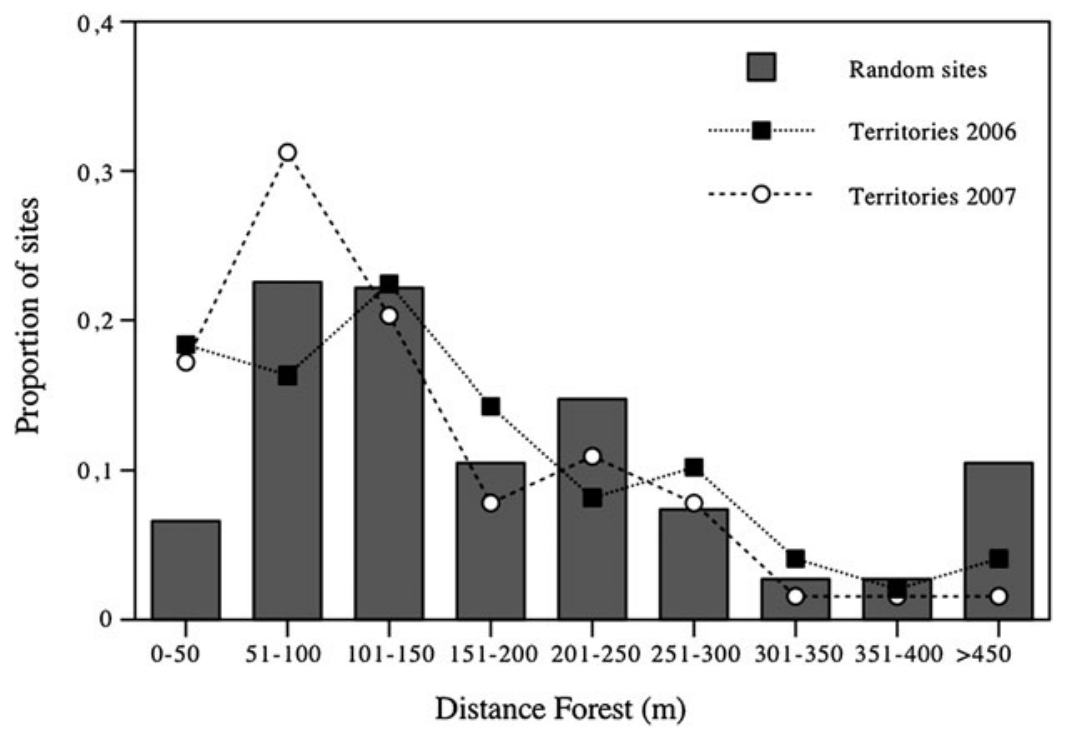

Fig. 2 Proportion of Corncrake territories (separate lines for 2006 and 2007) and random sites (bars) at different distances from forest edges (from territory centres).

sites, but the relative importance was intermediate $(<0.6)$ and the estimates of the effects of moisture were uncertain with confidence intervals including zero (Tables 3 and 4 ).

Many Corncrake territories were situated close to forest edges and a comparison of observed and random distribution of territories suggested no avoidance of forest edges (Fig. 2). The multimodel comparison of random sites and Corncrake territories showed that estimates for the effect of distance to forest edges were uncertain (Tables 3 and 4$)$. Areas close to forest edges $(<100 \mathrm{~m})$ harboured a substantial proportion of Corncrake territories in $2006(35 \%)$ and especially in 2007 $(48 \%)$, compared to the proportion of random sites within $100 \mathrm{~m}$ from edges $(29 \%)$. Sites at large distances from edges $(>300 \mathrm{~m})$ harboured a smaller proportion of territories $(5-10 \%)$, and this proportion was also smaller than the proportion of random sites (16\%).

Corncrakes were observed in a total of 100 different territories during the two years (defined as circles with $200 \mathrm{~m}$ radius). Only 13 of these territories were occupied both in 2006 and in 2007. Thus the location of territories varied widely between years (although the same grassland habitats were preferred in both years), as did the density of Corncrakes in the different study sites (Table 2). This change in territory location between years did not seem to be related to extensive land-use transitions, since $86.7 \%$ of the random points had the same habitat type (when classified as preferred or avoided habitat) in the two years. Changes from preferred to avoided habitats $(6.2 \%$ of the sites) and from avoided to preferred habitats (7.0 \%) were uncommon in the study sites. Corncrakes were often ( $75 \%$ of territories) aggregated in sites with several calling males close to each other $(<300 \mathrm{~m})$, suggesting that conspecific attraction might influence the settlement pattern of Corncrakes.

Mowing or clearing of vegetation occurred in $18(21.2 \%)$ of the 113 territories and in all cases the Corncrakes disappeared from these territories (birds were not observed after mowing, despite use of playback of calls on visits in July). In total, 65 of the territories (57.5\%) were situated on wet meadows used for mowing, leys or non-rotational set-asides that potentially could have been be influenced by mowing or clearing of vegetation later in the breeding season. 


\section{Discussion}

This study showed that unmanaged meadows (31\% of the territories) and mown wet meadows $(14 \%)$ with natural vegetation, as well as grasslands on arable fields such as leys $(30 \%)$ and nonrotational set-asides ( $15 \%$ of the territories), were preferred Corncrake habitats in the south-central Swedish farmland. This pattern was consistent between years and the habitat preferences were similar in early and late season (see also Berg 2008); in contrast to the situation in e.g. Alpine meadows where corncrakes were more abundant in high elevation sites late in the season (Brambilla and Pedrini in press). Previous, spatially more restricted, investigations have shown that wet meadows with tall vegetation were preferred in the region covered in this study (Berg and Gustafson 2007) whereas leys have been shown to be preferred on Öland in south-eastern Sweden (Ottvall and Pettersson 1998a,b). Preferences for set-asides have not been shown in earlier studies.

Measurements in the 12 study sites in 2006 showed that the mean vegetation height in Corncrake territories was $59 \mathrm{~cm}$, which was much higher than vegetation height at random points $(31 \mathrm{~cm})$, see Berg (2008). This preference for grasslands with tall vegetation is in line with earlier investigations showing avoidance of fields with low vegetation during spring (spring-sown crops, autumn sown crops, rotational set-asides, cultivated pastures and grazed wet meadows), although autumn-sown crops might be preferred in countries with earlier vegetation development (Schäffer and Münch 1993, Green and Stowe 1993, Stowe et al. 1993, Green et al. 1997, Schäffer 1999, Berg and Gustafson 2007). These preferences might be due to better shelter in areas with high vegetation, but food availability might also be higher in areas with high vegetation, especially in meadow habitats were no agrochemicals are used.

Many management-dependent, wet meadow birds (e.g. Lapwing Vanellus vanellus, Yellow Wagtail Motacilla flava, Meadow pipit Anthus pratensis, Curlew Numenius arquata and Redshank Tringa totanus) avoid nesting in areas close to forest edges (Stroud et al. 1990, Berg et al. 1992, Wallander et al. 2006), probably due to increased nest predation risks. In contrast, a large proportion of Corncrake territories were situated within $100 \mathrm{~m}$ of forest edges (Fig. 2). This might be an effect of more suitable habitat being available close to edges and not a preference for edges per se. Nevertheless, this difference between management-dependent species and the Corncrake should be used in planning of management of larger wet meadows. Corncrake habitats (unmanaged areas or less intensively managed areas) could be maintained and created close to forest edges ( $<$ 100 $\mathrm{m}$ ), while more intensive management should be concentrated on open wet meadow areas $(>100 \mathrm{~m}$ from edges) that are preferred by many ground nesting passerines and waders.

Ditches were more common within Corncrake territories than in random sites. Corncrakes might be attracted to the tall vegetation along ditches, but also to the moist conditions. Sites with ditches were preferred both on arable fields (leys and set-asides) and on meadows. Thus, moist sites with ditches in sown or natural grasslands with tall vegetation are suitable Corncrake habitats. In contrast, ditches might be avoided by other species in areas with short vegetation (Valkama et al. 1998) due to increased predator activity along linear features (Seymour et al. 2003). Tall vegetation could therefore also be maintained along ditches (also on meadows), especially in forested landscapes.

The percentage of territories influenced by management (mowing, clearing of vegetation) during the breeding season (here investigated until 20 July) was $21 \%$ (minimum value), but could have been as high as $58 \%$ later in the season. All Corncrakes disappeared from these territories after mowing or clearing of vegetation. The large difference between observed frequency of disturbance and expected frequency of disturbance was at least partly due to postponed mowing at one site with a large number of calling Corncrakes (Marma Skjutfält in 2007). Furthermore, many set-asides were not cleared of vegetation before the last visit (5-20 July) due to restrictions on clearing vegetation on set-asides before 1 July. Therefore, several of these fields were probably cleared of vegetation later in the season. Thus, avoidance of hay cutting or clearing in Corncrake territories would have large positive effects on breeding Corncrakes (see also Schäffer and Weisser 1996, Tyler et al. 1998). Postponing the first date for clearing of vegetation until I 
August (or even later) would positively affect Corncrake reproduction (see also Pettersson 2007). A similar postponement of mowing on wet meadows, and especially on intensively managed leys, is problematic since the nutritional value of the harvested grass will be limited (Spörndly et al. 2005). A suitable model would be voluntary postponement of harvesting on parts of the field ( $1-2$ ha) where Corncrakes have been reported, with economic compensation for the economic loss through agri-environment payments.

A strategy for conservation of Corncrake populations should focus on maintenance of wet meadows with tall vegetation. Target areas should be situated in forested landscapes, or parts of large meadow areas adjacent to forests since other management-dependent passerines and waders avoid these areas. Target areas should also be moist (usually adjacent to wetlands or have ditches). Several measures would increase the area of suitable meadow habitats for Corncrakes. Increased use of mowing instead of grazing could create preferred habitats and benefit Corncrakes; although this might be in conflict with many ongoing conservation programmes that aim to benefit biodiversity by increasing grazing. Mowing with intervals of a few years in suitable areas is a management regime that seems to be suitable since long-term yearly mowing might result in short vegetation (Berg and Gustafson 2007), although this management regime requires further evaluation. Currently unmanaged meadow habitats with suitable tall vegetation will in the long term be overgrown with shrubs and finally turn into swamp forests. The national goal of a $20 \%$ population increase by 2011 (Pettersson 2007) probably requires restoration of additional overgrown wet meadow areas (clearing of shrubs and accumulated litter) in order to increase the area of suitable habitat. In addition the strategy should include changed management on arable fields with tall grass vegetation. Mowing of set-asides should be postponed to August, and patches (I-2 ha) should be left unharvested on leys with Corncrakes.

\section{Acknowledgements}

Thanks to Robert Ström, Miroslav Kutal, Pekka Westin, Mats Edholm, Markus Rehnberg, Mikael Rhönnstad, Tommy Löfgren and Oskar Löfgren for censusing Corncrakes and mapping of habitats. Robert Ström distributed aerial photographs of the study areas. Länsstyrelsen i Västmanlands län financed the study within the "Action programmes for threatened species". Thanks to Thomas Pettersson and Tomas Pärt for comments on earlier versions of the manuscript.

\section{References}

Andrén, H. (1995) Effects of habitat edge and patch size on bird-nest predation. In: L. Hansson, L. Fahrig and G. Merriam, eds. Mosaic landscapes and ecological processes. London: Chapman and Hall.

Barton, K. (2010) MuMIn. Multi-model inference. R-package, version 0.13.17. Available at: http://CRAN.R-project.org/package $=$ MuMIn.

Bates, D. and Maechler, M. (2010) lme4. Linear mixed-effects models using $\mathrm{S}_{4}$ classes. R package, version 0.999375-37. Available at: http://CRAN.R-project.org/package =lme4.

Berg, A. (2002) Composition and diversity of bird communities in Swedish forestfarmland mosaic landscapes. Bird Study 49: 153-165.
Berg, Å. (2008) Standardiserad inventering av kornknarr (Crex crex) i Västmanlands och Uppsala län 2006-2007. Rapport 2008:21, Länsstyrelsen i Västmanlands Län. (In Swedish).

Berg, Å. and Gustafson, T. (2007) Meadow management and occurrence of Corncrake Crex crex. Agricult. Ecosys. Environ. 120: 139-144.

Berg, Å., Lindberg, T. and Källebrink, K. (1992) Hatching success of lapwings on farmland: differences between habitats and colonies of different sizes. J. Anim. Ecol. 61: 469-476.

Bernes, C. (1993) Nordens miljö - tillstånd, utveckling och hot. Monitor 13. Solna: Naturvårdsverket. (In Swedish). 
BirdLife International. (2004) Birds in the European Union: a status assessment. Wageningen, The Netherlands: BirdLife International.

Brambilla, M. and Pedrini, P. (in press). Intraseasonal changes in local pattern of Corncrake Crex crex occurrence require adaptive conservation strategies in Alpine meadows. Bird Conservation International doi: 10.1017/So959270910000572.

Burnham, K. P. and Anderson, D. R. (2002) Model selection and multi-model inference a practical information theoretical approach. New York: Springer.

Chamberlain, D. E. and Fuller, R. J. (200o) Local extinctions and changes in species richness of lowland farmland birds in England and Wales in relation to recent changes in agricultural land-use. Agricult. Ecosys. Environ. 78: 1-17.

Evans, K. L. (2004) The potential for interactions between predation and habitat change to cause population declines of farmland birds. Ibis 146: 1-13.

Gärdenfors, U., ed. (2010) Rödlistade Arter $i$ Sverige 2010 - The 2010 Red List of Swedish species. Uppsala: Artdatabanken, SLU. (In Swedish).

Green, R. E. (2008) Demographic mechanism of a historical bird population collapse reconstructed using museum specimens. Proc. R Soc. (Biol.) 275: 2381-2387.

Green, R. E. and Stowe, T. J. (1993) The decline of the corncrake Crex crex in Britain and Ireland in relation to habitat change. J. Appl. Ecol. 30: 689-695.

Green, R. E., Rocamora, G. and Schäffer, N. (1997) Population, ecology and threats to the Corncrake Crex crex in Europe. Vogelwelt 118: 117-134.

Gustafson, T. (2006) Bird communities and vegetation on Swedish wet meadows. Importance of management regimes and landscape composition. Doctoral thesis No. 2006:99. Faculty of natural resources and agricultural sciences. SLU, Uppsala.

Herzon, I. and Helenius, J. (2008) Agricultural drainage ditches, their biological importance and functioning. Biol. Cons. 141: $1171-1183$.

Herzon, I. and O'Hara, R. B. (2007) Effects of landscape complexity on farmland birds in the Baltic States. Agricult. Ecosys. Environ 118: 297-306.

IUCN 2010. IUCN Red List of threatened species. Version 2010.4. <www.iucnredlist.org $>$. Downloaded on 7 February 2011.

Keiss, O. (1997) Results of a randomised Corncrake Crex crex survey in Latvia 1996. Population estimates and habitat selection. Vogelwelt 118: 231-235.

Keiss, O. and Mednis, A. (2006) Impacts of land-use on the Corncrake population in Latvia: Trends and population structure. J. Orn. 147: 192.

Ottvall, R. and Pettersson, J. (1998a) Kornknarrens Crex crex biotopval, revirstorlek och ortstrohet på Öland: en radiosändarstudie. Orn. Svec.8: 65-76.

Ottvall, R. and Pettersson, J. (1998b) Is there a viable Corncrake Crex crex population on Öland, south-eastern Sweden? Habitat preferences in relation to hay-mowing activities. Orn. Svec. 8: 157-166.

Pärt, T. and Söderström, B. (1999) The effects of management regimes and location in landscape on the conservation of farmland birds breeding in semi-natural pastures. Biol. Conserv. 90: 113-123.

Pettersson, T. (2007) Åtgärdsprogram för kornknarr 2007-2010. Stockholm: Naturvårdsverket.

R Development Core Team (2010) R: A language and environment for statistical computing. R Foundation for Statistical Computing, Vienna, Austria. ISBN 3-900051-07-o, URL http://www.R-project. org.

Schäffer, N. (1999) Habitatwahl und Partnerschaftssystem von Tüpfelralle Porzana porzana und Wachtelkönig Crex crex. Ökol. Vögel 21: 1-267.

Schäffer, N. and Münch, S. (1993) Untersuchungen zur Habitatwahl und Brutbiologie des Wachtelkönigs Crex crex im Murnauer Moos/Oberbayern. Vogelwelt 114: 55-72.

Schäffer, N. and Weisser, W. W. (1996) A strategy for the conservation of the Corncrake Crex crex. J. Orn. 137: 53-75.

Seymour, A. S., Harris, S., Ralston, C., White, P. C. L. (2003) Factors influencing nesting success of Lapwing Vanellus 
vanellus and behaviour of Red Fox Vulpes vulpes in Lapwing nesting sites. Bird Study 50: $39-46$.

Spörndly, E., Lifvendahl, Z., Berg, Å. and Gustafson, T. (2005) Herbage from wet semi-natural meadows. 2. Nutrient content of some dominating species during different parts of the season. $\mathrm{P} 298$ in $\mathrm{E}$. Strandberg, E. Cenkvári, E. von Borell, B. Kemp, C. Lazzoroni, M. Gauly, C. Wenk, W. Martin-Rosset, A. Bernués Jal and C. Thomas, eds. Book of abstracts of the 56 th annual meeting of the European Association for Animal Production (EAAP). Uppsala, Sweden, 5-8 June 2005.

Stowe, T, J., Newton, A. V., Green, R. E. and Mayes, E. 1993. The decline of the corncrake Crex crex in Britain and Ireland in relation to habitat. J. Appl Ecol. 30: 5362.

Stroud, D. A., Reed, T. M. and Harding, N. J. (1990) Do moorland breeding waders avoid plantation edges? Bird Study 37: 177-186.

Tyler, G. A., Green, R. E. and Casey, C. (1998) Survival and behaviour of Corncrake Crex crex chicks during mowing of agricultural grassland. Bird Study 45: 35-50.

Valkama, J., Robertson, P. and Currie, D. (1998) Habitat selection by breeding curlews (Numenius arquata) on farmland: the importance of grassland. Ann. Zool. Fenn. 35: 141-148.

Wallander, J., Isaksson, D. and Lenberg, T. (2006) Wader nest distribution in relation to man-made structure on coastal pastures. Biol. Conserv. 136: 136-142.

\section{ÅKE BERG*}

The Swedish Biodiversity Centre, Swedish University of Agricultural Science (SLU), Box 7007, SE-750 o7 Uppsala, Sweden.

\section{MATTHEW HIRON}

The Department of Ecology, Swedish University of Agricultural Science (SLU), Box 7044, SE750 o7 Uppsala, Sweden.

*Author for correspondence; e-mail: ake.berg@slu.se

Received 9 November 2010; revision accepted I March 2011;

Published online 7 September 2011 